\title{
Diagnostic significance and source of lactate dehydrogenase and its isoenzymes in cerebrospinal fluid of children with a variety of neurological disorders
}

\author{
P. V. NELSON, W. F. CAREY, AND A. C. POLlaRd ${ }^{1}$ \\ From the Department of Chemical Pathology, Adelaide Children's Hospital (Incorporated), \\ 72 King William Road, North Adelaide, S.A. 5006
}

SYNOPSIS Two hundred and thirty-four cerebrospinal fluid (CSF) specimens from 183 different children were analysed for total lactate dehydrogenase (LD) activity and LD isoenzyme distribution. The LD activities were elevated in the CSF of patients with meningitis, especially with bacterial infections, and with central nervous system (CNS) leukaemia. The CSF LD isoenzyme patterns of both groups generally reflected the number and distribution of lymphocytes and granulocytes in the CSF.

Increases in CSF LD levels also occurred in patients with other neurological disorders, such as hydrocephalus, raised intracranial pressure, and epileptic seizures. However, no significant increases in CSF LD activity nor abnormality of the isoenzyme distribution were noted in childreif who had had a non-specific febrile convulsion.

Estimations of serum aspartate aminotransferase (AST; L-aspartate: 2-oxoglutarate aminotransferase, EC 2.6.1.1), lactate dehydrogenase (LD; L-lactate: NAD oxidoreductase, EC 1.1.1.27), and creatine kinase (CK; ATP: creatine phosphotransferase, EC 2.7.3.2) are widely employed as valuable diagnostic aids in diseases involving necrosis or damage of tissues characteristically rich in these enzymes. The activities of these three enzymes have been measured in the CSF of patients with a variety of neurological disorders (Lisak and Graig, 1967; Katz and Leibman, 1970; Williams and Hawkins, 1968; Mellick and Bassett, 1964; Jakoby and Jakoby 1958; Lending, Slobody and Mestern, 1964). The results obtained, however, are of uncertain diagnostic significance. The LD activity consistently demonstrates a proportionally higher elevation than AST and CK in all disorders where any increase in enzyme activity occurs and therefore appears the most sensitive and, in this context, potentially the most useful index of neurological disorder. More recently, attempts have been made to identify the source(s) of the CSF LD activity with a view to increasing

${ }^{1}$ Reprint requests and correspondence should be addressed to Dr A. C. Pollard, Director of Chemical Pathology.

Received for publication 31 December 1974. diagnostic specificity (Beaty and Oppenheimer, 1968; van der Halm, Zondag, and Klein, 1963). It has been proposed that lymphocytes and/or granulocytes are the sources of LD activity in meningitis but that brain tissue is the source in other neurological disorders not involving leucocytosis of the CSF. However, neither proposition has been demonstrated conclusively.

The work presented here attempts to correlate CSF LD activity, LD isoenzyme distribution, total protein and glucose as well as total and differential leucocyte counts in order to assess the diagnostic usefulness of CSF LD activity in children with various neurological disorders.

\section{Patients}

The patients included in this survey were unselected save that a sufficient volume of CSF remained for enzyme studies after orthodox routine tests had been performed. Sixty-one (61) patients whose final diagnosis was primarily non-neurological, for example, respiratory tract infections or gastroenteritis, were used as the 'normal' or reference group.

One hundred and twenty-two (122) individual patients comprised the study group (table I). The 828 


\begin{tabular}{|c|c|c|}
\hline Final Diagnosis & No. of Patients & $\begin{array}{l}\text { No. of CSF Samples } \\
\text { from Each Group of Patients }\end{array}$ \\
\hline & $(T o t a l=122)$ & $($ Total $=173)$ \\
\hline $\begin{array}{l}\text { Bacterial meningitis } \\
\text { Acute phase } \\
\text { Later stages }\end{array}$ & $\begin{array}{l}12^{1} \\
23\end{array}$ & $\begin{array}{l}12 \\
51\end{array}$ \\
\hline Viral meningitis (diagnosed clinically) & 10 & 10 \\
\hline $\begin{array}{l}\text { Acute lymphatic leukaemia } \\
\text { without CNS involvement } \\
\text { with CNS infiltration }\end{array}$ & 5 & $\begin{array}{r}6 \\
11\end{array}$ \\
\hline Hydrocephalus (for shunt insertion or revision) & 9 & 10 \\
\hline $\begin{array}{l}\text { Miscellaneous neurological disorders } \\
\text { (includes } 5 \text { post grand mal epileptic seizures) }\end{array}$ & 30 & 39 \\
\hline Febrile convulsion (non-specific) & 34 & 34 \\
\hline
\end{tabular}

Table I Patient study group-diagnostic categories

${ }^{1} 6$ of these 12 patients were also subsequently included in the 23 comprising the 'later stage' category.

final diagnostic categorization of each patient was made without reference to the enzyme data.

\section{Methods}

The CSF specimens were obtained by lumbar puncture; macroscopically bloodstained specimens were discarded. The other samples were centrifuged at approximately $10000 \times \mathrm{g}$ for 3 minutes at room temperature to remove intact cells.

The following procedures were routinely performed on all CSF specimens; protein (Pennock, Passant, and Bolton, 1968) and glucose (Glucose Analyser $^{1}$ ); analysis for total and differential leucocyte count; Gram stain, and culture on blood agar and heated blood agar. Total CSF LD activity was determined on cell free fluid by a modification of the spectrophotometric method of Henry, Chiamori, Golub and Berkman (1960) at $340 \mathrm{~nm}$ and $30^{\circ} \mathrm{C}$; enzyme activities were reported as $\mu$ moles/ $\min 1^{-1}(U / 1)$.

If sufficient sample was available the CSF specimens were then concentrated approximately 10 -fold by ultrafiltration in a collodion bag ${ }^{2}$ (pore size $8 \mathrm{~m} \mu$ ) against a negative pressure of $17 \mathrm{lb} / \mathrm{in}^{2}$. Separation of the LD isoenzymes was performed by electrophoresis on Sephraphore III strips ${ }^{3}$ using 0.05 M barbitone buffer pH 9.0 (ionic strength $=0.075$ ) and 12.5 volt $/ \mathrm{cm}$ for 1.25 hours. The LD isoenzyme bands were stained using the method of di Giorgio (1971). A visual qualitative assessment of the relative intensities of staining of each isoenzyme band was made, the fastest moving, most anodal band being designated 1 , the slowest moving, most cathodal being designated 5 ; bands 2,3 , and 4 are intermediate in mobility. In the text and tables the indi-

1Beckman Instruments Inc, Fullerton, Calif. 92534, USA
'Sartorius Membranfilter, 34 Gottingen, Germany

${ }^{3}$ Gelman Instrument Company, Ann Arbor, Michigan, USA vidual isoenzyme bands are listed from left to right in order of decreasing activity: the principal band(s) is/are underlined; a band just visible is recorded in parenthesis.

Postmortem cortical brain tissue (1g) was obtained within 12 hours of death from a neurologically normal child, homogenized in $20 \mathrm{ml}$ of cold $\left(4^{\circ} \mathrm{C}\right)$ physiological saline (0.155 M) with a glass mortar and pestle and then centrifuged at $3000 \times \mathrm{g}$ for 10 minutes. The supernatant was used to determine the LD isoenzyme pattern of brain tissue.

Lymphoblasts were obtained from the blood of a child with untreated acute lymphatic leukaemia (ALL). Lymphocytes and granulocytes were acquired from the blood of healthy hospital personnel. The individual leucocyte species were separated by differential centrifugation through a two-phase discontinuous density gradient composed of Ficoll ${ }^{4}$ and sodium diatrizoate (Cruikshank and Hay, 1973). The cells were then washed twice with physiological saline and then resuspended in physiological saline to give approximately $9 \times 10^{5}$ cells $/ \mathrm{ml}$. The cells were disrupted ultrasonically by treatment for 10 seconds at half power with a Technic International Sonicator (Sonipen ${ }^{5}$ ), then centrifuged at $3000 \times \mathbf{g}$ for 10 minutes to remove cell fragments, and the supernatants were used to determine the characteristic LD isoenzyme patterns of each tissue.

\section{Results}

\section{MENINGITIS}

Bacterial Infections

Table II gives the CSF data from the 12 children lumbar punctured during the early, acute (granulocytic) phase of the infection. The LD activity is seen

4Pharmacia, Uppsala, Sweden

${ }^{5}$ Bergenfield, NJ 97621, USA 


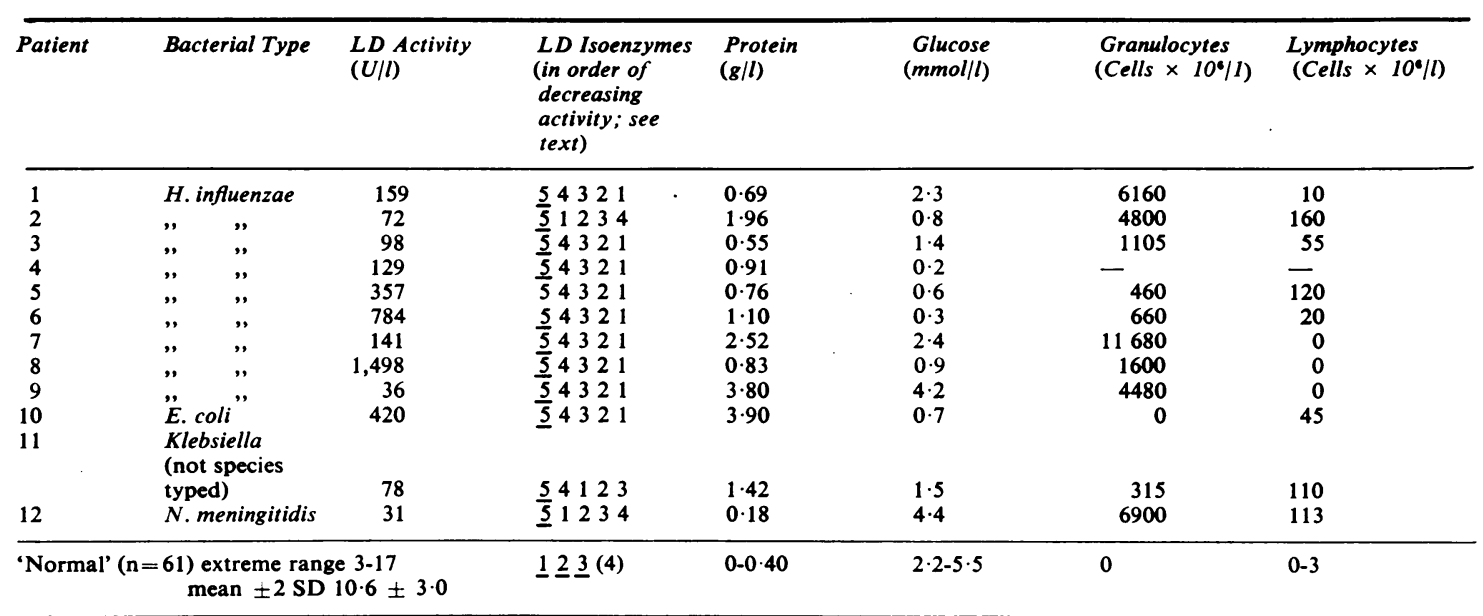

Table II CSF data from children with bacterial meningitis during acute (polymorph) stage of infection - test not carried out

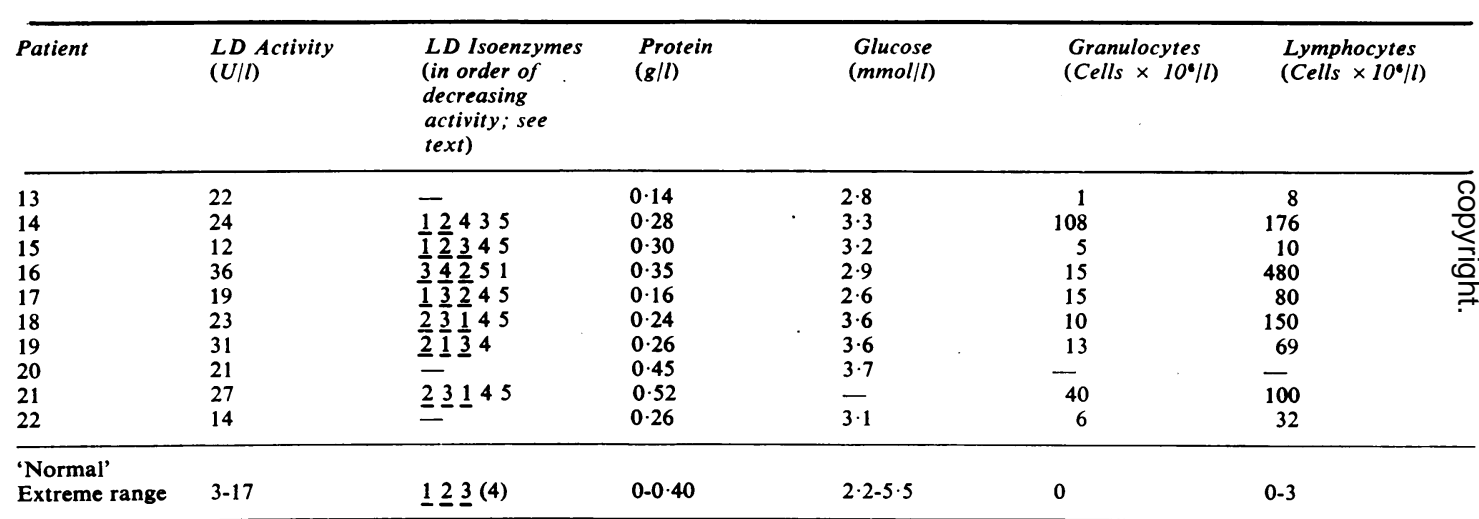

Table III CSF data from children with viral meningitis

- test not carried out

\begin{tabular}{|c|c|c|c|c|c|c|c|}
\hline Patient & Date & $\begin{array}{l}\text { LD Activity } \\
(U / l)\end{array}$ & $\begin{array}{l}\text { LD Isoenzymes } \\
\text { (in order of } \\
\text { decreasing } \\
\text { activity; see } \\
\text { text) }\end{array}$ & $\begin{array}{l}\text { Protein } \\
(g / l)\end{array}$ & $\begin{array}{l}\text { Glucose } \\
(\mathrm{mmol} / \mathrm{l})\end{array}$ & $\begin{array}{l}\text { Granulocytes } \\
\left(\text { Cells } \times 10^{6} / l\right)\end{array}$ & $\begin{array}{l}\text { Mononuclear } \\
\left(\text { Cells } \times 10^{4} / l\right)\end{array}$ \\
\hline $\begin{array}{l}23 \\
\text { " } \\
\ddot{24} \\
25 \\
26 \\
\ddot{27} \\
" \\
",\end{array}$ & $\begin{aligned} & 13 \text { Feb } \\
& 16 \text { Feb } \\
& 21 \text { June } \\
& 26 \text { June } \\
& \\
& 26 \text { Mar } \\
& 19 \text { June } \\
& 12 \text { June } \\
& 4 \text { July } \\
& 11 \text { July }\end{aligned}$ & $\begin{array}{r}156 \\
64 \\
118 \\
55 \\
43 \\
140 \\
47 \\
16 \\
33 \\
30 \\
30\end{array}$ & 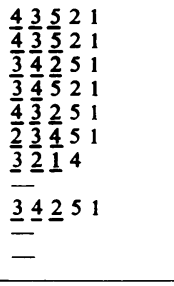 & $\begin{array}{l}1.32 \\
0.54 \\
0.70 \\
0.72 \\
0.95 \\
1.04 \\
0.82 \\
0.39 \\
0.21 \\
0.18 \\
0.20\end{array}$ & $\begin{array}{l}- \\
- \\
0 \cdot 5 \\
1 \cdot 3 \\
2 \cdot 5 \\
0 \cdot 6 \\
3 \cdot 2 \\
3 \cdot 3 \\
2 \cdot 3 \\
\overline{2 \cdot 9}\end{array}$ & $\begin{array}{l}0 \\
0 \\
0 \\
0 \\
0 \\
0 \\
0 \\
0 \\
0 \\
0 \\
0\end{array}$ & $\begin{array}{r}1180 \\
470 \\
770 \\
210 \\
320 \\
452 \\
19 \\
6 \\
710 \\
27 \\
17\end{array}$ \\
\hline $\begin{array}{l}\text { Norma } \\
\text { Extrem }\end{array}$ & & $3-17$ & $12 \underline{3}(4)$ & $0-0.40$ & $2 \cdot 2-5 \cdot 5$ & 0 & $0-3$ \\
\hline
\end{tabular}

Table IV CSF data from children with leukaemic infiltration of CNS

- test not carried out 
to vary widely from approximately double to nearly 100 times the highest value seen in the normal. The most prominent isoenzyme is invariably LD 5 . However, CSF specimens taken at later (lymphocytic) stages of the infection were found to show lower, but still abnormal LD activity, but in these cases the predominating isoenzymes were LD 2, 3 , and 1 .

\section{Viral Infections}

Table III shows that in these situations CSF LD activity is almost invariably slightly elevated; LD 1 and 2 are usually the prominent isoenzymes, and at the same time the fluids are predominantly lymphocytic.

\section{LYMPHATIC LEUKAEMIC INFILTRATION OF THE CNS}

The data obtained from repeated CSF specimens taken at random stages of the disease are presented in Table IV. CSF taken from the five leukaemic children without CNS infiltration, on the other hand, revealed no abnormalities in any of the parameters studied.

OTHER PATIENT GROUPS

CSF data relating to the other patient groups are summarized in Table V.

\begin{tabular}{|c|c|c|}
\hline Patient Group & \multicolumn{2}{|c|}{$\begin{array}{l}\text { LD Activity } \\
(U / D)\end{array}$} \\
\hline Hydrocephalus & $17-537$ & In all cases the predominant \\
\hline $\begin{array}{l}\text { Miscellaneous: } \\
\text { Epileptics (5) } \\
\text { Raised i/c pressure } \\
\text { Birth trauma } \\
\text { Brain tumour } \\
\text { Febrile convulsions }\end{array}$ & $\left.\begin{array}{r}17-28 \\
19-55 \\
3-21\end{array}\right\}$ & $\begin{array}{l}\text { LD isoenzymes were } 1,2 \text {, } \\
\text { and } 3 \text {; protein levels and white } \\
\text { cell counts were usually normal } \\
\text { but sometimes very slightly } \\
\text { elevated }\end{array}$ \\
\hline 'Normal' & $3-17$ & \\
\hline
\end{tabular}

Table V CSF data from other patient groups

TISSUE EXTRACTS

Extracts of all body tissues considered as potential sources of CSF LD were analysed to determine their characteristic LD isoenzyme pattern. Results obtained are presented in table VI.

\section{Discussion}

Not unexpectedly, the CSF LD activity tended to increase together with the CSF protein level, but the direct correlation was poor $(r=0.27)^{1}$. Of the 234 CSF specimens examined, 49 had a normal

${ }^{\mathbf{1}_{\mathbf{r}}}=$ correlation coefficient

\begin{tabular}{ll}
\hline Tissue & $\begin{array}{l}\text { LD Isoenzyme Pattern } \\
\text { (in order of decreasing } \\
\text { activity; see text) }\end{array}$ \\
\hline $\begin{array}{l}\text { Blood granulocyte } \\
\text { Blood lymphocyte } \\
\text { Blood lymphoblast } \\
\text { Brain tissue }\end{array}$ & $\underline{5} 432(1)$ \\
\hline
\end{tabular}

Table VI LD isoenzyme distributions in white cell and brain tissue extracts

protein level but at the same time an elevated LD activity. Most of these 49 samples were from children who were finally considered or proved to suffer from neurological illness. In only one case was the LD activity normal and the CSF protein elevated. It would thus appear that LD activity is a more sensitive index of neurological disorder than CSF protein level. CSF LD activities greater than $60 \mathrm{U} / 1$ are indicative of either bacterial meningitis or CNS leukaemia while mildly elevated levels (20 U/1 to $50 \mathrm{U} / 1$ ) can be the result of one of a multitude of causes. Thus while remaining a sensitive index of CNS disorder, CSF LD activity is of little specific diagnostic value. Non-specific febrile convulsions do not result in an elevation in CSF LD values above the 'normal' group; it may, however, be of clinical interest to note that in all five cases of epileptic convulsions $L D$ values were greater than the presently determined upper limit of normal. These results are compatible with those obtained elsewhere (Williams and Hawkins, 1968; Jakoby and Jakoby, 1958; Lending et al, 1964; Beaty and Oppenheimer, 1968).

The CSF LD isoenzyme patterns characteristic of each neurological disorder investigated in this study also compare with the results of previous reports (Beaty and Oppenheimer, 1968; van der Halm, Zondag and Klein, 1963). However, a comparison of the CSF LD isoenzyme patterns with those obtained from tissue extracts (table VI), and with the differential leucocyte counts of the CSF specimens, allow us to postulate with a little more certainty the source of CSF LD activity.

The data show that in the CSF, LD 5 and granulocytes are usually detected together (eg, table II); similarly, LD 3, 2, and 4 are usually present in association with lymphocytes. The characteristic LD isoenzyme patterns of granulocyte and lymphocyte extracts have been shown to be LD $5,4,3,2,(1)$ and $\mathrm{LD} 3 \underline{3}, 2,4,(1,5)$ respectively (table VI). It thus appears most probable that the major source of $L D$ activity in CSF specimens showing leucocytosis is the white cells.

This correlation between cell types and LD isoenzymes in cases of bacterial meningitis is most 


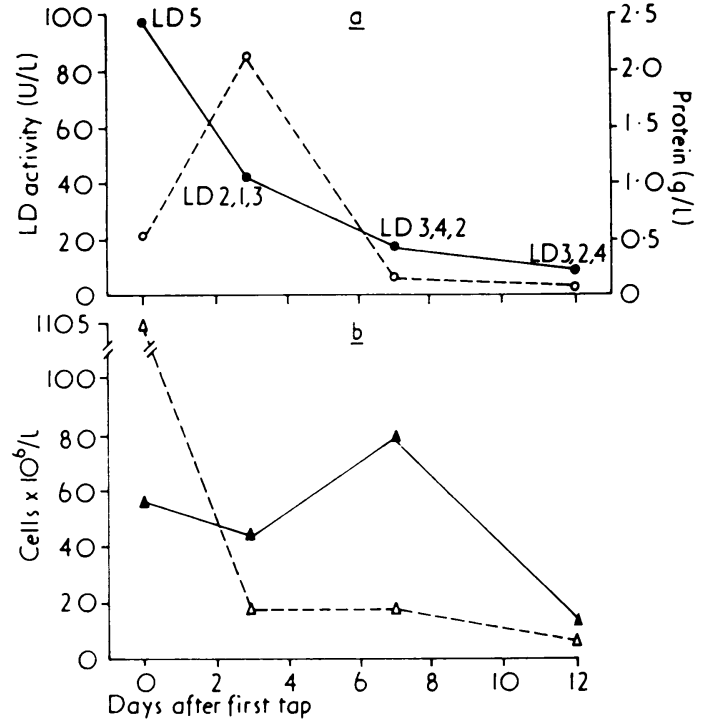

Figure Serial analyses of CSF specimens from a child (patient 3, table II) with bacterial meningitis:
(a) LD activity, 0 ; protein, $\bigcirc--\bigcirc$ :
(b) lymphocyte count, $\Delta-\Delta ;$ granulocyte count, $\triangle--\triangle$.

clearly demonstrated by the data obtained from a serial analysis of the CSF of patient 3 (figure). On admission the child presented with an excess of granulocytes in the CSF, an elevated LD activity with LD 5 being the major isoenzyme detected in the CSF. During the later stages of the infection lymphocytes became the dominant white cell type, and LD 3, 2, and 4 simultaneously became the major isoenzyme bands.

There was one exception to this correlation (table II, patient 10); the CSF LD isoenzyme pattern showed an excess of LD 5, but no granulocytes were seen in the CSF. However, a CSF specimen taken two days earlier, upon which enzyme studies were not possible, showed on routine examination that it contained 880 granulocytes $\times 10^{6} / 1$ and 35 lymphocytes $\times 10^{6} / 1$. Therefore, it is possible that in some cases the CSF LD pattern may represent the CSF leucocyte status of a few days earlier. But for the most part there was a direct correlation between CSF LD isoenzyme pattern and leucocyte type in children with bacterial meningitis.

Viral infections of the CNS resulted in only mild elevation of the LD activity and leucocyte count (table III). Correspondingly, the LD isoenzyme patterns also varied but slightly from normal;
P. V. Nelson, W. F. Carey, and A. C. Pollard

LD 2, 1, and 3 predominated. This LD isoenzyme pattern suggests a combined role of lymphocytes and brain tissue (table VI) as the source of LD activity in these patients.

The CSF samples from the acute lymphatic leukaemia patients characteristically showed large mononucleated cell populations, either lymphocytes and/or lymphoblasts (table IV). The CSF LD isoenzyme patterns of these patients correspond closely with either lymphocyte or lymphoblast extract patterns (table VI) or a combination of both, thereby strongly supporting the concept of a leucocytic origin of LD in the CSF of these children as well.

The LD was often elevated in the CSF of children with non-specific hydrocephalus (table V), raised intracranial pressure, and many other neurological $\circ$ disorders, although leucocytosis was not present. The LD isoenzyme patterns are basically similar in all these disorders, that is, the predominant isoenzymes are LD 1, 2, and 3. This pattern suggests that damage to brain tissue may be the source of the LD activity (table VI) (van der Halm, Zondag, and Klein, 1963; van der Halm, 1962).

By comparing the characteristic LD isoenzyme $\overrightarrow{0}$ patterns of the tissues in contact with the CSF ov with the CSF isoenzyme patterns of children wi通 neurological disorders, it has been possible to demofis strate more clearly the sources of LD in the CSE Where leucocytosis of the CSF occurs the cells appear to be the source of LD activity, but in all other cases it seems possible that brain cell damage releases the enzyme into the CSF.

From the foregoing it appears that CSF LD 3 activity is a more sensitive indicator of CNS pathology than is the protein level; however, it is non-specific. LD isoenzyme patterns, while $\overline{ }$ offering a little more in specificity, in general reveal little more than the orthodox differential leucocyte 3 . count. Raised CSF 1 and 2, without the presence $\delta$ of leucocytes in the CSF, may indicate brain cell damage.

We should like to thank the Department of Bacterio- $\frac{D}{0}$ logy of the Adelaide Children's Hospital for supplying the routine cytological and bacteriological data $\widetilde{N}$ presented in this paper and, similarly, to thank the N members of the Department of Haematology for N their assistance in preparing lymphocyte, lymphoblast, and granulocyte extracts.

\section{References}

Beaty, H. N. and Oppenheimer, S. (1968). Cerebrospinal- $T$ fluid lactic dehydrogenase and its isoenzymes in infections

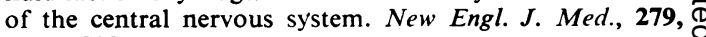
1197-1202. 
Cruikshank, J. A. and Hay, J. (1973). A rapid and reliable micro-method of leukoagglutination using papain. Tissue Antigens, 3, 57-62.

di Giorgio, J. (1971). Determination of serum lactic dehydrogenase isoenzymes by use of the "Diagnostest" cellulose acetate electrophoresis system. Clin. Chem., 17, 326-331.

van der Halm, H. J. (1962). Isoenzymes in different parts of the brain. J. Neurochem., 9, 325-327.

van der Halm, H. J., Zondag, H. A., and Klein, F. (1963). On the source of lactic dehydrogenase in cerebrospinal fluid. Clin. chim. Acta, 8, 193-196.

Henry, R. J., Chiamori, N., Golub, O. J., and Berkman, S. (1960). Revised spectrophotometric methods for the determination of glutamic-oxalacetic transaminase, glutamic-pyruvic transaminase, and lactic acid dehydrogenase. Amer. J. clin. Path., 34, 381-398.

Jakoby, R. K. and Jakoby, W. V. (1958). Lactic dehydrogenase of cerebrospinal fluid in the differential diagnosis of cerebrovascular disease and brain tumour.J. Neurosurg . $15,45-51$.
Katz, R. M. and Leibman, W. (1970). Creatine phosphokinase activity in central nervous system disorders and infections. Amer. J. Dis. Child., 120, 543-546.

Lending, M., Slobody, L. B., and Mestern, J. (1964) Cerebrospinal fluid glutamic oxalacetic transaminase and lactic dehydrogenase activities in children with neurologic disorders. J. Pediat., 65, 415-421.

Lisak, R. P. and Graig, F. A. (1967). Lack of diagnostic value of creatine phosphokinase assay in spinal fluid J. Amer. Med. Ass., 199, 750-751.

Mellick, R. S. and Bassett, R. L. (1964). Cerebrospinalfluid glutamic oxalacetic transaminase activity in neurologic diseases. Lancet, 1, 904-906.

Pennock, C. A., Passant, L. P., and Bolton, F. G. (1968). Estimation of cerebrospinal fluid protein. J. clin. Path., 21, 518-520.

Williams, R. D. B. and Hawkins, R. (1968). The clinical value of cerebrospinal fluid lactic dehydrogenase determinations in children with bacterial meningitis and other neurological disorders. Develop. Med. Child Neurol., 10, 711-714. 